\title{
EQUITY PARTICIPATION LEVEL OF MULTINATIONAL ENTERPRISES IN CROSS-BORDER MERGER AND ACQUISITIONS: A STUDY IN TURKEY CONTEXT ${ }^{*}$
}

\author{
ÇOK ULUSLU İ̧LETMELERİN ULUSLARARASI BİRLEŞME VE \\ SATIN ALMALARDAKİ MÜLKIYYET ORTAKLIĞI DÜZEYİ: TÜRKİYE \\ BAĞLAMINDA BİR ÇALIŞMA
}

\author{
Ayşe KAYACI ${ }^{* *}$ iD \\ Aylin ATAAY ${ }^{* * *}$ iD \\ Ömer DÜLEK ${ }^{* * *}$ iD
}

\begin{abstract}
This study tries to examine how industry and institutional environment differences in cross-border merger and acquisitions affect equity participation level of multinational enterprises in emerging markets. We have based our research model and hypotheses on transaction cost based and institution-based view. Since industry and institutional environment differences cause risk and uncertainty to MNEs which lead higher transaction costs for these firms, these two theoretical approaches would be still relevant to understand MNEs' strategic behavior in emerging market contexts. We have analyzed our hypotheses with a sample of completed cross-border merger and acquisitions between 1999-2017 in Turkey context via multiple regression analysis. Related secondary data collected at both country, industry and firm level. Our findings support the positive influence of industry relatedness on ownership participation but we cannot find support for the moderating influence of both formal and informal institutions on the relationship between

* This study was presented with the title of “Türkiyedeki Uluslararası Birleşme ve Satın Almalarda Mülkiyet Ortaklı̆̆ Düzeyi: Kurumsal ve Endüstriyel Etkiler” at 28. National Management and Organization Congress on 3-5 September 2020.

** Sorumlu Yazar: Assist. Prof., Dicle University, Faculty of Economics and Administrative Sciences, Department of Management, ayse.kayaci@dicle.ed.tr, ORCID: 0000-0001-5242-7805.

*** Prof. Dr., Galatasaray University, Faculty of Economics and Administrative Sciences, Department of Management, Corporate Governance Audit and Compliance Studies Application and Research Center, aataay@gsu.edu.tr, ORCID: 0000-0001-5150-1946.

**** Res. Asst., Dicle University, Faculty of Economics and Administrative Sciences, Department of Management, omerdulek@gmail.com, ORCID: 0000-0002-6343-6384.
\end{abstract}

To cite this article: Kayacı, A., Ataay, A. \& Dülek, Ö. (2021). Equity Participation Level of Multinational Enterprises in Cross-border Merger and Acquisitions: A Study in Turkey Context. Journal of Research in Business, 6(2), 381-400.

"There is no requirement of Ethics Committee Approval for this study." 
industry relatedness and equity participation level. Consequently, our study has shown that transaction cost-based view is still relevant for MNEs' foreign investment decisions in emerging markets like Turkey and despite institutional voids perspective, formal and informal institutions could not hinder MNEs to take risk in strategic choices.

Keywords: Cross-border merger and acquisitions, multinational enterprises, industry relatedness, institutional distance, Turkey

JEL Classification: M10, M16

Öz

$\mathrm{Bu}$ çalışmada gelişmekte olan ülkelerde gerçekleşen uluslararası birleşme ve satın almalarda tercih edilen mülkiyet ortaklığı düzeyinin endüstri ve kurumsal çevre farklılıklarından nasıl etkilendiği tespit edilmeye çalışılmıştır. Araştırma modelimiz ve hipotezlerimiz, işlem maliyeti ve kurumsal temelli bakış açısı etrafında oluşturulmuştur. Endüstri ve kurumsal çevre koşullarından kaynaklanan risk ve belirsizliğin çok uluslu işletmeler için daha yüksek işlem maliyetlerine yol açması, bu iki teorik bakış açısının çok uluslu işletmelerin gelişmekte olan ülkelerdeki stratejik davranışlarını açıklamakta hala geçerli olduğunu göstermektedir. Hipotezlerimiz, Türkiye'de 1999-2017 yılları arasında gerçekleştirilmiş uluslararası birleşme ve satın almalardan oluşan bir örneklemde çoklu regresyon yöntemi ile analiz edilmiştir. Ülke, endüstri ve firma düzeyinde ilgili ikincil veriler bir araya getirildi. Araştırma bulgularımız ilişkili endüstride olmanın sahiplik katılımı üzerindeki pozitif etkisini desteklemiştir fakat resmi ve gayrı resmi kurumların, ilişkili endüstri ve mülkiyet ortaklığı düzeyi arasındaki ilişkide düzenleyici etkisine dair dayanak bulunamamıştır. Sonuç olarak, çalışmamız işlem maliyeti temelli bakış açısının çok uluslu işletmelerin gelişmekte olan ülkelerdeki yabancı yatırımlarında hala geçerli olduğunu ve kurumsal boşluklar bakış açısının aksine resmi ve gayrı resmi kurumların çok uluslu işletmelerin stratejik tercihlerinde risk almalarını engelleyemediğini göstermiştir.

Anahtar Kelimeler: Uluslararası birleşme ve satın almalar, çok uluslu işletmeler, ilişkili endüstri, kurumsal mesafe, Türkiye

JEL Sınıflandırılması: M10, M16

\section{Introduction}

Cross-border merger and acquisitions (CBMAs) have been widely studied in international business (IB) literature since they provide advantages like economies of scale, exploiting foreign market opportunities and accessing rare resources for firms (Chakrabarti, Gupta-Mukherjee, \& Jayaraman, 2009: 216). Moreover CBMAs have been the main mode of foreign direct investment (FDI) since 1980s (UNCTAD, 2005: 4). As in Figure 1, both outward and inward FDI has shown an increasing trend since the beginning of 2000 globally. For the year of 2018, global amount of CBMAs have reached 816 billion US dollars value with 6821 number of deals. 127 billion US dollars of CBMAs have been completed in emerging and transition economies in the same year (UNCTAD, 2019: 8). Emerging markets (EMs) have become significant actors in global economy after 1980s liberalization policies in economies who want to imitate the success of "Asian Tigers". "Asian Tigers" are countries from south-east region of Asia and had accelerated economic and industrial development with neo-liberal economy policies and attracting FDI from advanced countries. EMs are still important locations with providing established and mature market opportunities, being attractive FDI destinations, sourcing significant assets for MNEs and ensuring speculated investment opportunities (Cavusgil, 2021: 1). On the other hand, EMs have institutional voids that make hard to invest and sustain business strategies for foreign MNEs that are not used to these environments (Khanna \& Palepu, 1997). At 
this point, deciding about ownership participation level in CBMAs would be more significant for MNEs since this decision would determine the success and survival of the acquiring firm in the host country (Chari \& Chang, 2009; Yang, 2015).

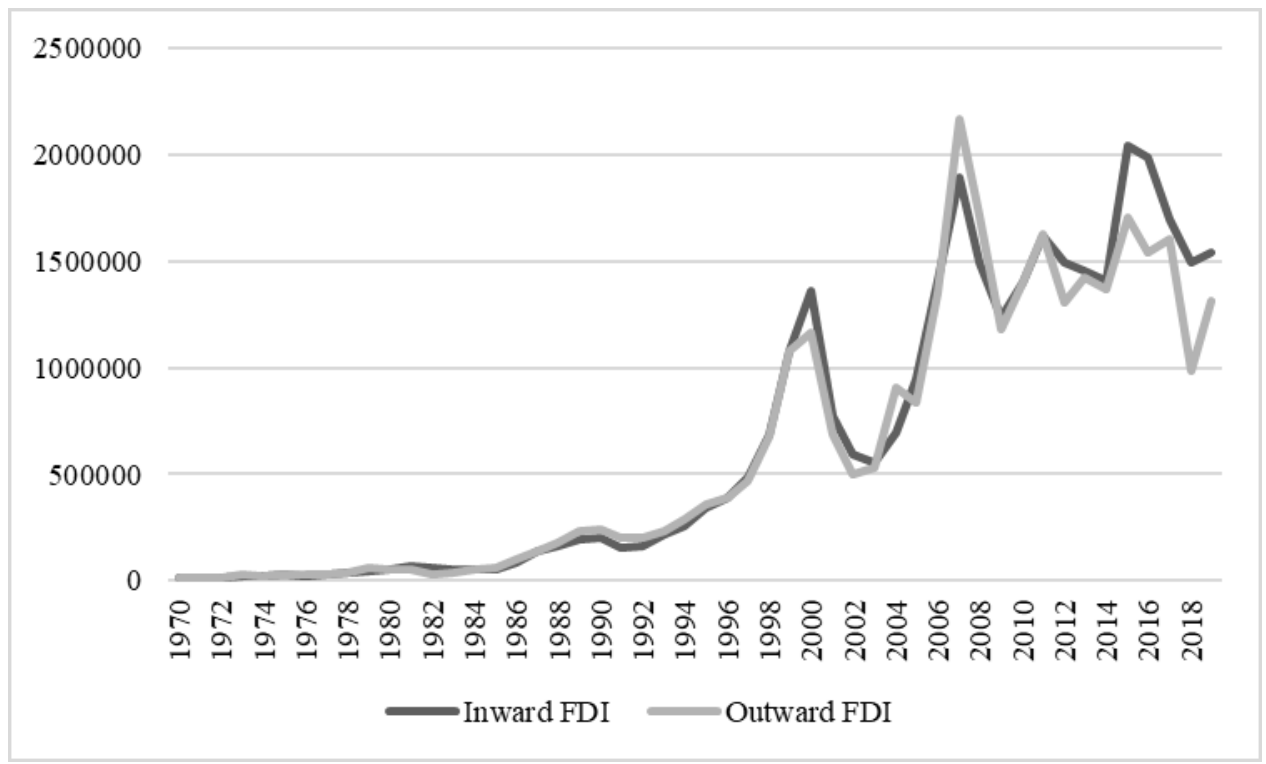

Figure 1: Foreign Direct Investment Stocks of World Economy (US Dollars in Millions) (Source: UNCTAD, 2021)

Most of the related literature about the determinants of equity participation level of MNEs in CBMAs has based on transaction costs and institution-based view (Chari \& Chang, 2009; Contractor, Lahiri, Elango, \& Kundu, 2014; Lahiri, Elango, \& Kundu, 2014; Liou, Chao, \& Ellstrand, 2017; Malhotra, Lin, \& Farrell, 2016; Yang, 2015). Relatedly, it is important to evaluate the findings regarding the relationships between the institutional and industrial environment and the ownership choice in foreign investments through different EM contexts. In this study, the main assumption is that MNEs will consider the real value of acquired resources and assets of the target firm and the institutional and industrial environmental conditions of host country when deciding about the ownership level in CBMAs (Yang, 2015). Consequently, transaction cost and institution-based views have been adopted to determine these conditions which have been manifested as formal and informal institutional distance and industry level factors for this study.

Related literature provides evidence that CBMAs in related industries would make MNEs to take more risk and involve in greater ownership in target firms (Contractor et al., 2014; Malhotra, Sivakumar, \& Zhu, 2011; Yang, 2015). However, we have limited information about determinants of equity participation level in CBMAs of MNEs in mid-range EMs like Turkey. Turkey serves as a good setting with its better infrastructural development but poor institutional environment to understand 
how industry related and institutional factors effect ownership level choice of MNEs (Hoskisson, Wright, Filatotchev, \& Peng, 2013). To fill this research gap, we have developed a multi-level model that considers both industry and country level factors which may affect equity participation level of MNEs in EMs. This study examined 1274 CBMAs completed in Turkey between 1999 and 2017. Our analyses have supported previous studies that focuses on the positive relationship between industry relatedness and ownership participation. On the contrary to our expectations, both formal and informal institutional distance have not diminished the positive effect of industry relatedness on equity participation level. Besides, informal institutional distance has increased the positive relationship between industry relatedness and ownership participation level. Our study has contributed to CBMAs literature by showing how industrial environment is significant for ownership decisions of MNEs in EMs. However, our study has contradicted with institutional voids perspective in EMs that would restrain MNEs for risk taking in investments.

Our paper has organized as follows. The next section summarized the related literature about CBMAs and our research model in general. In the third section, we have mentioned about research methodology which includes the sampling process and variable descriptions. The fourth chapter includes the results of the statistical analyses. Lastly, we have discussed our findings and summarized possible limitations and future research.

\section{Literature Review and Hypotheses}

\subsection{Ownership Level and Industry Relatedness in Cross-border Merger and Acquisitions}

According to resource-based view (RBV), MNEs consider mostly the target firm's valuable and complementary resources when making investments via CBMAs. CBMAs provide advantages for controlling, acquiring and exploiting of the shared resources of both target and acquirer firms (Haleblian, Devers, McNamara, Carpenter, \& Davison, 2009; Shimizu, Hitt, Vaidyanath, \& Pisano, 2004). The most significant decision in CBMAs after investment decision is the share of equity that the acquirer will own in target firm (Chari \& Chang, 2009; Chen, 2008). MNEs decide about ownership level in target firms by considering both the composition of valuable resources and assets of the target firm and the uncertainty related to industrial and institutional environments of target country. The transaction costs related to these circumstances and information asymmetry between acquirer and target firms would shape the decision about the equity level that MNEs will choose (Anderson \& Gatignon, 1986; Chari \& Chang, 2009; Chen \& Hennart, 2004). Internalizing the whole foreign operations within the MNE mainly considers transaction costs related to investment environment (Buckley \& Casson, 1976). MNEs would choose partial or full acquisition at this stage and they can fully control the whole revenues and assets of target firm in full acquisition (Brouthers \& Hennart, 2007). However, full acquisition entry mode also means more risk and uncertainty in foreign markets for MNEs by venturing more resources (Chari \& Chang, 2009). Information asymmetry problems would also increase for MNEs when acquiring and target firms are from different industries and institutional environments which also led more risk for acquiring firms (Shimizu et al., 2004; Yang, 2015). The determination of target firm's real value and contribution to 
acquiring firm would cause many complexities for MNEs since it is difficult to determine the exact value of proprietary assets of target firm. Relatedly, entry mode decisions of MNEs are affected by transaction costs, factors and risks relevant to institutional and cultural contexts of target countries (Brouthers, 2002). Previous research about the relationship between institutional and industrial environment and equity participation level of MNEs in CBMAs has shown diverse findings (Chari \& Chang, 2009; Contractor et al., 2014; Lahiri et al., 2014; Liou et al., 2017; Malhotra et al., 2016; Yang, 2015). These studies have mostly tried to explain the influential factors of equity participation level in CBMAs via transaction cost-based view and institution-based view. Similarly, this study would embrace both transaction cost and institution-based view to examine how both formal and informal institutional distances and industry conditions would shape ownership level decision of MNEs while investing in EMs like Turkey.

The information related to industry and industrial environment is significant for MNEs when venturing in foreign markets through CBMAs. Industry and industrial environment information and knowledge would decrease both uncertainty about investment activities and information asymmetry with target firm (Contractor et al., 2014; Yang, 2015). Since MNEs prefer CBMAs more than other FDI entry modes to reach target firm's tacit knowledge and technology immediately, they would also prefer acquisitions in related industries due to uncertainty avoidance (Yin \& Shanley, 2008). Investing in a related industry is more preferable for firms for its possible higher return and lower-level perceived risk (Lim \& Lee, 2016). Furthermore, CBMAs compose diverse factors to complete a deal and maintain integration process between acquirer and target firms (Di Guardo, Marrocu, \& Paci, 2016). For instance, Contractor et al. (2014) have found that MNEs prefer full or majority level of ownership in target firms more than minority ownership if acquirer and target firms are in the same industry in the contexts of China and India. Although EMs are not seen as homogenous by scholars since they demonstrate different ranges of institutional and infrastructural developments, they mostly generate institutional voids for both domestic and foreign firms in business environment (Hoskisson et al., 2013; Khanna \& Rivkin, 2001). Turkey also has inadequate institutional development despite its better infrastructural development in mid-range EMs (Hoskisson et al., 2013). Due to these circumstances, MNEs would prefer to lower uncertainty and risk in FDI decisions and similar industry environments may serve for this. Even if, Turkey's underdeveloped institutional environment would increase risk for MNEs in ownership decisions, industry relatedness can decrease the harmful effect of institutional environment on higher level of control in target firms. For this reason, MNEs would also prefer higher level of equity participation in CBMAs if both firms are from similar industry while investing in Turkey. Thus, our first hypothesis is:

Hypothesis 1: MNEs would prefer higher level of equity participation in Turkish firms when acquirer and target firms are from related industries. 


\subsection{The Role of Institutional Distance in Cross-border Merger and Acquisitions}

In the early entry mode choice literature, differences between institutional environments are seen as one of the reasons for higher transaction costs (Williamson, 1979) due to the uncertainty that is produced by these environments and as a result, it is expected that the firms would prefer to avoid ownership alternatives implying higher equity participations as ownership choices when entering into foreign markets (Gatignon \& Anderson, 1988). This situation emerges since institutions are significant structures that form both formal and informal rules and they are vital in the formation of firm strategy and behavior (North, 1990; Peng, Sun, Pinkham, \& Chen, 2009). While formal institutions include a country's laws, regulations, legislations and common law and shape institutional environment mostly, informal institutions mean values, cultural norms and language of a given country (Arslan \& Dikova, 2015, p. 235; Contractor et al., 2014, p. 933). As formal and informal institutions differ between host and home countries, it would become more difficult for MNEs to gain legitimacy and to operate in host country environment (Anderson \& Gatignon, 1986; Brouthers, 2002; Kostova \& Zaheer, 1999). As a consequence of this, MNEs may prefer to lower their investments in the target country or their equity participation in the target firm when institutional distance between home and host regions increase. Moreover, MNEs tend to lower their ownership level in foreign acquisitions if the host country is an EM (Chari \& Chang, 2009; Demirbag, Glaister, \& Tatoglu, 2007; Lahiri, 2017). The main reasons of this are high uncertainty and transaction costs related to institutional voids and underdeveloped factor markets in EMs (Khanna \& Palepu, 1997). Similarly, Turkey as a mid-range EM, has infrastructural development above the average but it has a poor institutional environment which makes majority acquisitions risky for MNEs (Hoskisson et al., 2013). It could be expected that the uncertainty related to formal institutional environment of Turkey would negatively affect the equity participation level of MNEs in CBMAs. Relatedly, informal institutional distance would also have a negative effect on the ownership level of MNEs in CBMAs since informal institutions are more implicit than formal institutions in target countries. As the distance between cultures and implicit norms between home and host regions increase, MNEs prefer lower level of equity participation in their CBMAs (Chen \& Hennart, 2004; Contractor et al., 2014; Demirbag et al., 2007). Moreover, both formal and informal institutional environments would shape industries in a given country since they provide a wider environmental layer for all firms. Malhotra et al. (2011) have found that the higher cultural distance lowers the equity participation level of MNEs but this relationship is weaker for acquisition deals in related industries. Consequently, the ownership level of MNEs in target firms would be affected negatively by the uncertainty caused by formal and informal institutions even if the acquirer and target firms are from related industries.

Hypothesis 2a: The positive relationship between industry relatedness and equity participation level of MNEs would be lower as the formal institutional distance between home country and Turkey increases.

Hypothesis 2b: The positive relationship between industry relatedness and equity participation level of MNEs would be lower as the informal institutional distance between home country and Turkey increases. 
The developed hypotheses of the study have been summarized in the research model and depicted in Figure 2.

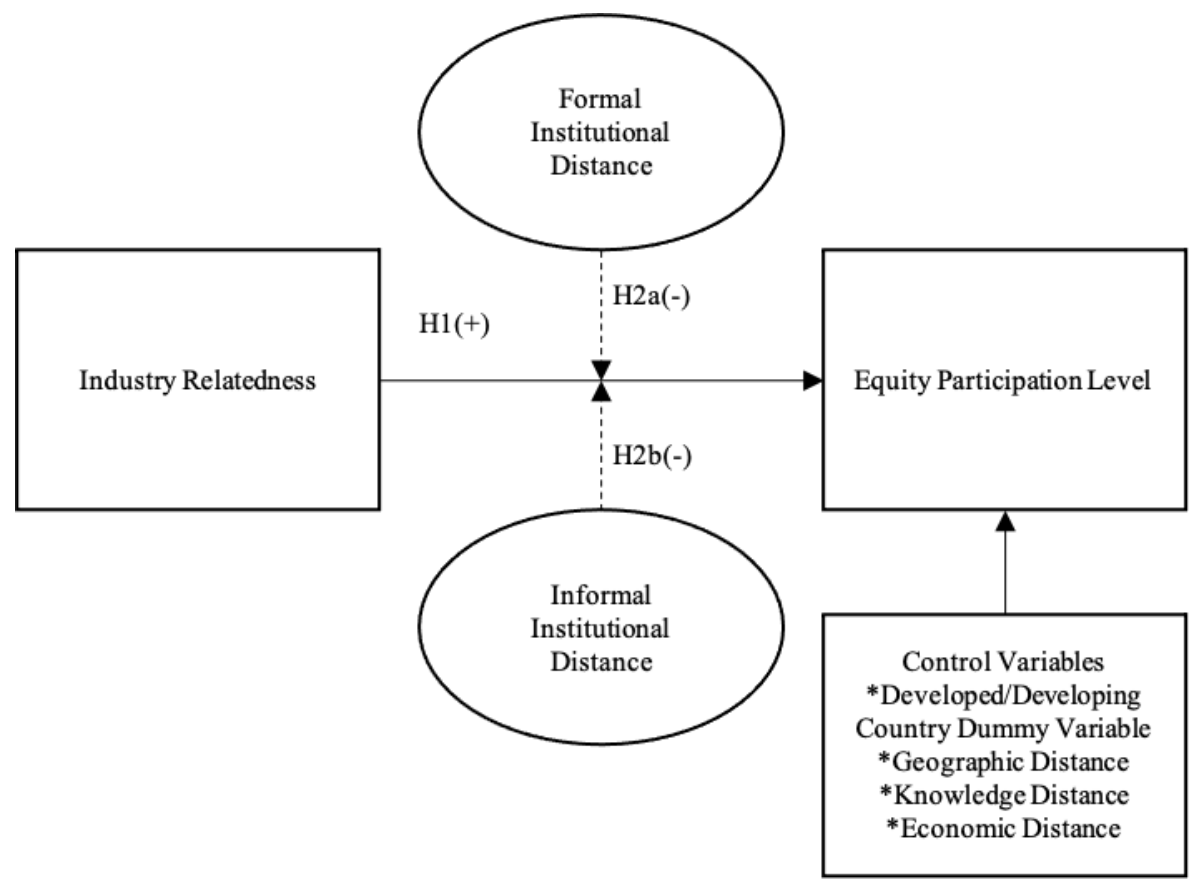

Figure 2: Research Model

\section{Method}

\subsection{Sampling}

The sample of the research consists of 1274 cross border merger and acquisitions (CBMA) activities carried out by foreign MNEs in Turkey between 1999 and 2017. The CBMA data is gathered from Thomson ONE database which is a widely used and reliable data source for merger and acquisition deals since it provides detailed information about every deal (Buckley, Elia, \& Kafouros, 2014; Caprio, Croci, \& Del Giudice, 2011). We have used all completed CBMA deals in Turkey that have recorded by Thomson ONE database. Thomson ONE recorded Turkey related data since 1999. By this way, we have expanded our sample for a wide range time span. We have ensured that all deals are completed and the information of target and acquiring firm is at satisfactory levels. Turkey serves as a good context to understand how EM contexts would define MNEs ownership choices in CBMAs. As can be seen in Figure 3, Turkey has been an important FDI destination since the beginning of 1990s with its liberalization efforts in economy and business (Demirbag et al., 2007). Turkey's market size and attractiveness, infrastructural development and open market economy supported FDI inflows to 
Turkey (Erdal \& Tatoglu, 2002). Moreover, mature industries are common business areas for most of the firms in the country which can be a significant resource pool for foreign MNEs (Colpan \& Hikino, 2008). MNEs generally prefer acquisitions over greenfield investment when entering Turkish market. Furthermore, MNEs FDI decisions in Turkey have shown similar patterns with previous literature according to studies of Turkey context (Demirbag et al., 2007; Demirbag, Tatoglu, \& Glaister, 2008; Erdal \& Tatoglu, 2002). For these reasons, investigating CBMAs in Turkey for the related period in Turkey's economy can give new insights.

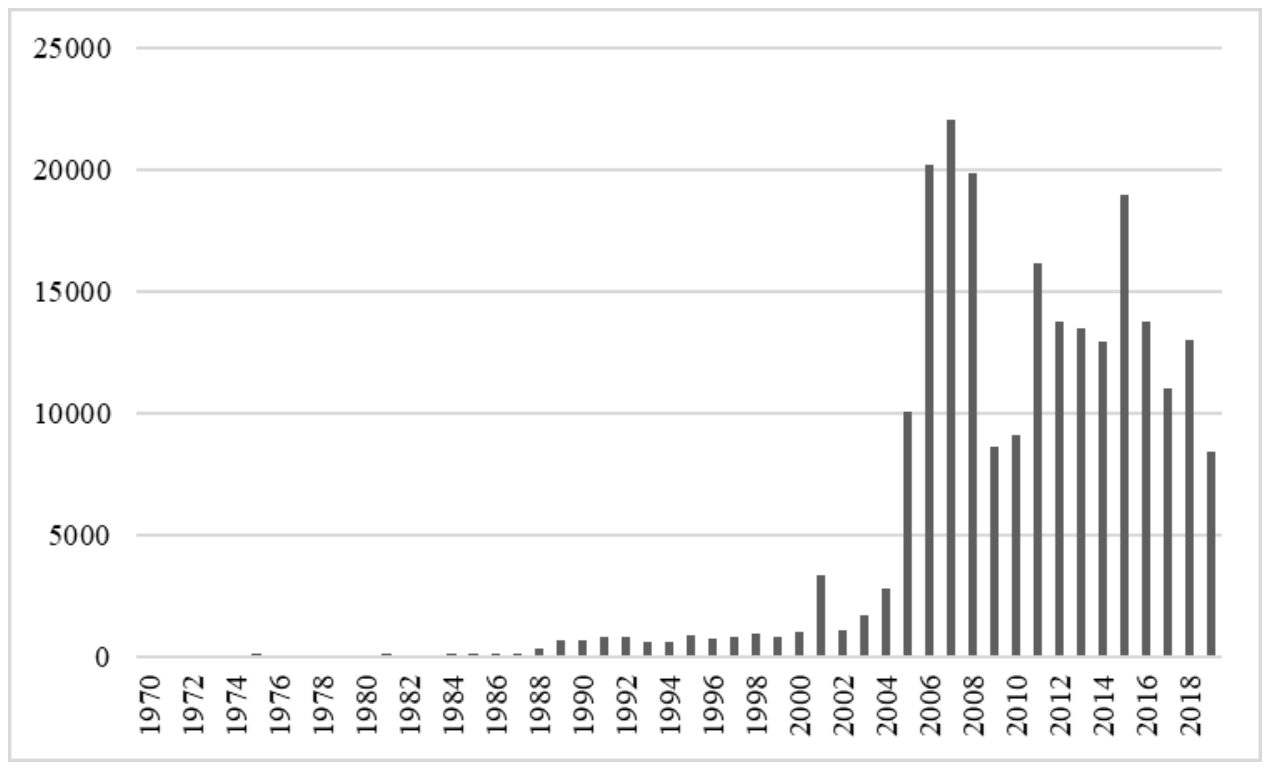

Figure 3: Inward FDI of Turkey (US Dollars in Millions) (Source: UNCTAD, 2021)

\subsection{Variable Measurement}

The dependent variable of this study is equity participation level of MNEs in Turkish firms. This variable is measured as the percentage level of equity that MNEs obtain during CBMA deal and ranges between $0.1 \%$ to $100 \%$. This measure is available Thomson ONE database for each completed deal. This measurement has been common in the literature since its continuous nature (Liou et al., 2017; Malhotra et al., 2011; Yang, 2015). This measure is more accurate than classifying ownership levels as minority, majority and full ownership since it can easily differentiate the real effect of changes between 50\% and 75\% equity participation in CBMA deals than evaluating them in the same ownership level (Chen \& Hennart, 2004; Yang, 2015). By this way, the statistical power of the analyses can be guaranteed (Fitzsimons, 2008). 
The independent variable of the study is industry relatedness and is measured by a dummy variable according to industry information of target and acquiring firms in Thomson ONE database. If the target and acquiring firm from the same industry, the value is " 1 " and " 0 " otherwise.

The first moderator variable is formal institutional distance and is measured by World Governance Indicators (WGI) developed by Kaufmann et al. (2011). WGI have six sub dimensions (voice and accountability, political stability, government effectiveness, regulatory quality, rule of law and control of corruption) and data related to these qualifications have been collected since 1996 worldwide by Worldbank. These indicators have been widely used by researchers to measure institutional quality of countries in IB field. Each sub dimension and the overall measure takes value between - 2.5 to 2.5 and higher values mean that the related country has higher institutional quality (Dikova, 2009; Lahiri et al., 2014; Yang, 2015). To compute this variable, we have used the formula of Morosini, Shane and Singh (1998) below:

$$
I D_{h t}=\sqrt{\sum_{i=1}^{6}\left(I_{i h}-I_{i t}\right)^{2}}
$$

where,

$I D_{h t=}$ Formal institutional distance between MNE's home country and Turkey

$I_{i h}=$ Governance index score of home country

$I_{i t}=$ Turkey's governance index score

Informal institutional distance has been measured by Kogut and Singh's (1988) formula. Since national culture provide important insights about informal institutions of a country, we have used four cultural dimensions of Hofstede (2001) to operationalize this formula (Contractor et al., 2014; Dikova, 2009):

$$
C D=\sum_{j=1}^{4} \frac{\left(H_{H, j}-H_{T, j}\right)^{2}}{4 x V_{j}}
$$

where,

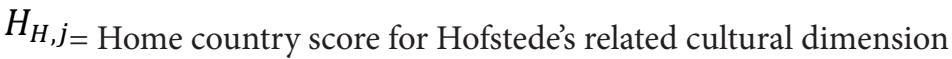

$H_{T, j}=$ Turkey's score for Hofstede's related cultural dimension

$V_{j=\text { Variance of index of Hofstede's related cultural dimension }}$ 
We have operationalized some control variables which could have effects on equity participation level of MNEs. Our first control variable is about whether MNEs' home country is a developed or developing (emerging) country which would supply significant insights about institutional distance effect on ownership participation. This variable is a dummy coded variable which takes value of " 1 " if the home country is developed and " 0 " if the home country is a developing (emerging) country according International Monetary Fund classification. Other control variables are geographic, economic and knowledge distance that were derived from Berry et al. (2010)'s database. These variables also could have important impacts on MNEs ownership participation decisions in CBMAs.

\section{Findings}

As can be seen in Table 1, most of the MNEs have advanced home countries which have completed CBMAs in Turkey for the period of 1999-2017. Target firms are mainly from manufacturing (33\%), services (18\%), finance, insurance, real estate (15\%) and transportation and public utilities (15\%) industries in our sample. On the other hand, acquirer firms are mostly from financials (36\%), materials (14\%) and industrials (10\%). It also seems that home country of MNEs are mainly from North America and Europe continents which includes Canada (14\%), USA (13\%), United Kingdom and Germany (8\%) in general.

Table 1: Descriptive Statistics of Sample

\begin{tabular}{lllll}
\hline Variable & Level & Counts & Total & Proportion \\
\hline IMF Group & Advanced & 1056 & 1274 & $83 \%$ \\
& Emerging & 218 & 1274 & $17 \%$ \\
\cline { 2 - 3 } & Agriculture Forestry Fishing & 15 & 1274 & $1 \%$ \\
& Construction & 15 & 1274 & $1 \%$ \\
& Finance Insurance Real Estate & 194 & 1274 & $15 \%$ \\
& Manufacturing & 425 & 1274 & $33 \%$ \\
& Mining & 83 & 1274 & $7 \%$ \\
Acquiror Industry & 2 & 1274 & $0 \%$ \\
& Public Administration & 52 & 1274 & $4 \%$ \\
& Retail Trade & 224 & 1274 & $18 \%$ \\
& Services & 186 & 1274 & $15 \%$ \\
& Transportation and Public Utilities & 78 & 1274 & $6 \%$ \\
& Consumer Staples & 87 & 1274 & $7 \%$ \\
& Energy and Power & 88 & 1274 & $7 \%$ \\
& Financials & 87 & 1274 & $7 \%$ \\
& Government and Agencies & 458 & 1274 & $36 \%$ \\
& Healthcare & 13 & 1274 & $1 \%$ \\
& High Technology & 47 & 1274 & $4 \%$ \\
& Industrials & 61 & 1274 & $5 \%$ \\
& & 121 & 1274 & $10 \%$
\end{tabular}




\begin{tabular}{|c|c|c|c|c|}
\hline & Materials & 173 & 1274 & $14 \%$ \\
\hline & Media and Entertainment & 60 & 1274 & $5 \%$ \\
\hline & Real Estate & 28 & 1274 & $2 \%$ \\
\hline & Retail & 36 & 1274 & $3 \%$ \\
\hline & Telecommunications & 15 & 1274 & $1 \%$ \\
\hline \multirow[t]{18}{*}{$\begin{array}{l}\text { MNE Country of } \\
\text { Origin }\end{array}$} & Canada & 173 & 1274 & $14 \%$ \\
\hline & USA & 161 & 1274 & $13 \%$ \\
\hline & United Kingdom & 104 & 1274 & $8 \%$ \\
\hline & Germany & 103 & 1274 & $8 \%$ \\
\hline & France & 92 & 1274 & $7 \%$ \\
\hline & Netherlands & 77 & 1274 & $6 \%$ \\
\hline & Italy & 39 & 1274 & $3 \%$ \\
\hline & Japan & 40 & 1274 & $3 \%$ \\
\hline & UAE & 38 & 1274 & $3 \%$ \\
\hline & Austria & 33 & 1274 & $3 \%$ \\
\hline & Switzerland & 33 & 1274 & $3 \%$ \\
\hline & Spain & 31 & 1274 & $2 \%$ \\
\hline & Greece & 27 & 1274 & $2 \%$ \\
\hline & Belgium & 26 & 1274 & $2 \%$ \\
\hline & Saudi Arabia & 24 & 1274 & $2 \%$ \\
\hline & Luxembourg & 20 & 1274 & $2 \%$ \\
\hline & Sweden & 19 & 1274 & $2 \%$ \\
\hline & Other & 234 & 1274 & $18 \%$ \\
\hline
\end{tabular}

According to results in Table 2, moderate level of correlations between variables have been found. The correlations between IMF grouping and formal institutional distance $(0.648, \mathrm{p}<0.01)$, geographic and knowledge distance $(0.590, \mathrm{p}<0.01)$ and formal and informal institutional distance $(0.535, \mathrm{p}<0.01)$ are not so high, so multicollinearity would not be a problem for the study.

Table 2: Pearson Correlations

\begin{tabular}{llllllll}
\hline Variable & $\mathbf{1}$ & $\mathbf{2}$ & $\mathbf{3}$ & $\mathbf{4}$ & $\mathbf{5}$ & $\mathbf{6}$ & $\mathbf{7}$ \\
\hline 1. IMF Grouping & 1 & & & & & & \\
2. Geographic Distance & $0.091^{* *}$ & 1 & & & & & \\
3. Knowledge Distance & $0.320^{* * *}$ & $0.590^{* * *}$ & 1 & & & & \\
4. Economic Distance & $0.069^{*}$ & $-4.834 \mathrm{e}-4$ & 0.058 & 1 & & & \\
5. Industry Relatedness & 0.030 & $-0.165^{* * *}$ & 0.001 & $-0.075^{*}$ & 1 & & \\
6. Formal Institutional Distance & $0.648^{* * *}$ & $0.130^{* * *}$ & $0.174^{* * *}$ & $0.318^{* * *}$ & $-0.073^{* *}$ & 1 & \\
7. Informal Institutional Distance & $0.421^{* * *}$ & $0.353^{* * *}$ & $0.438^{* * *}$ & 0.015 & $-0.057^{*}$ & $0.535^{* * *}$ & 1 \\
\hline
\end{tabular}

${ }^{*} \mathrm{p}<.05,{ }^{* *} \mathrm{p}<.01,{ }^{* * *} \mathrm{p}<.001$

The analysis of the relationship between the variables was carried out with a multiple regression analysis and the results are summarized in Table 3. All models comprising variables were tested with 
the Breusch-Pagan/Cook-Weisberg test in terms of homogeneous variance assumption. As we found that the chi-square values were insignificant for all models, we concluded that the heteroscedasticity problem is not an issue for any of our models. In Model 1, among all the control variables of the study, only CBMAs of developed countries and economic distance have a significant effect on the acquisition equity level. We observe that the acquisition level was positively affected in the CBMA activities carried out by the developed country's MNEs $(\beta=7.147 ; \mathrm{p}<0.05)$ and furthermore the equity participation level decreases $(\beta=-0.476 ; \mathrm{p}<0.01)$ as the economic distance between the countries increases.

Table 3: Results of Multiple Regression

\begin{tabular}{|c|c|c|c|c|}
\hline Variables & Model 1 & Model 2 & Model 3 & Model 4 \\
\hline \multirow[t]{2}{*}{ Developed Country } & $7.147^{\star *}$ & $7.201^{* *}$ & 6.103 & $7.146^{* *}$ \\
\hline & (3.124) & $(3.121)$ & $(4.131)$ & $(3.421)$ \\
\hline \multirow[t]{2}{*}{ Geographic Distance } & -0.000 & 0.000 & 0.000 & 0.000 \\
\hline & $(0.000)$ & $(0.000)$ & $(0.000)$ & $(0.000)$ \\
\hline \multirow[t]{2}{*}{ Knowledge Distance } & 0.122 & 0.086 & 0.060 & 0.087 \\
\hline & $(0.149)$ & $(0.150)$ & $(0.153)$ & $(0.154)$ \\
\hline \multirow[t]{2}{*}{ Economic Distance } & $-0.476^{\star * *}$ & $-0.453^{\star * *}$ & $-0.489^{* * *}$ & $-0.495^{\star * *}$ \\
\hline & $(0.173)$ & $(0.174)$ & $(0.188)$ & $(0.175)$ \\
\hline \multirow[t]{2}{*}{ Industry Relatedness } & & $3.770^{*}$ & $4.083^{\star}$ & $3.690^{*}$ \\
\hline & & $(2.138)$ & $(2.149)$ & $(2.149)$ \\
\hline \multirow[t]{2}{*}{ Formal Institutional Distance } & & & -0.888 & \\
\hline & & & $(2.084)$ & \\
\hline \multirow[t]{2}{*}{ Formal Institutional Distance X Related Industry } & & & 3.329 & \\
\hline & & & $(2.269)$ & \\
\hline \multirow[t]{2}{*}{ Informal Institutional Distance } & & & & $-2.873^{*}$ \\
\hline & & & & $(1.658)$ \\
\hline Informal Institutional Distance $\mathrm{X}$ Related & & & & $4.526^{* *}$ \\
\hline Industry & & & & $(1.929)$ \\
\hline \multirow[t]{2}{*}{ Constant } & $62.379^{* * *}$ & $59.660^{* * *}$ & -5.476 & -6.088 \\
\hline & $(3.282)$ & $(3.623)$ & $(4.558)$ & $(4.014)$ \\
\hline Observation number & 1,003 & 1,003 & 1,003 & 993 \\
\hline$R^{2}$ & 0.015 & 0.018 & 0.020 & 0.021 \\
\hline Breushc-Pagan test (Chi-square) & 1.03 & 0.00 & 0.09 & 0.07 \\
\hline
\end{tabular}

Hypothesis 1 was supported according to the results of Model 2, which analyzed the assumption that the industry relatedness will positively affect the percentage of equity acquired by MNEs in the target company. We found that industry relatedness had a significant and positive effect $(\beta=3.770$; $\mathrm{p}<0.1)$ on the equity participation level in acquisitions, in other words if the acquirer and acquired companies operate in the same industry, the acquisition ownership level increases. In order to prevent 
the multicollinearity problem that may arise in both Model 3 and Model 4 where the moderation effects were tested, dependent and moderator variables were centralized and then analyzed (Aiken \& West, 1991). However, Hypothesis 2a, which suggests that formal institutional distance will weaken the strength of the positive relationship between the industry relatedness and the equity participation level, was not supported based on the results of Model 3. Similarly, Hypothesis 2b, which proposes that the informal institutional distance between home and host countries will weaken the positive relationship between the industry relatedness and the equity participation level, revealed a significant but a positive effect $(\beta=4.526 ; \mathrm{p}<0.05)$ in Model 4. In other words, contrary to the expectations, the increase in the cultural distance between the home country and Turkey further strengthens the positive relationship between the industry relatedness and the acquisition ownership level. Thus, Hypothesis $2 \mathrm{~b}$ is not supported.

Simple slope analysis was also applied in order to see more clearly the impacts of formal and informal institutional distance variables on the relationship between the industry relatedness and the equity participation level. The effects of these two moderating variables on the relationship between the independent and dependent variables for the mean, below-mean and above-mean values are shown in Figure 2, Figure 3, Table 4 and Table 5 respectively.

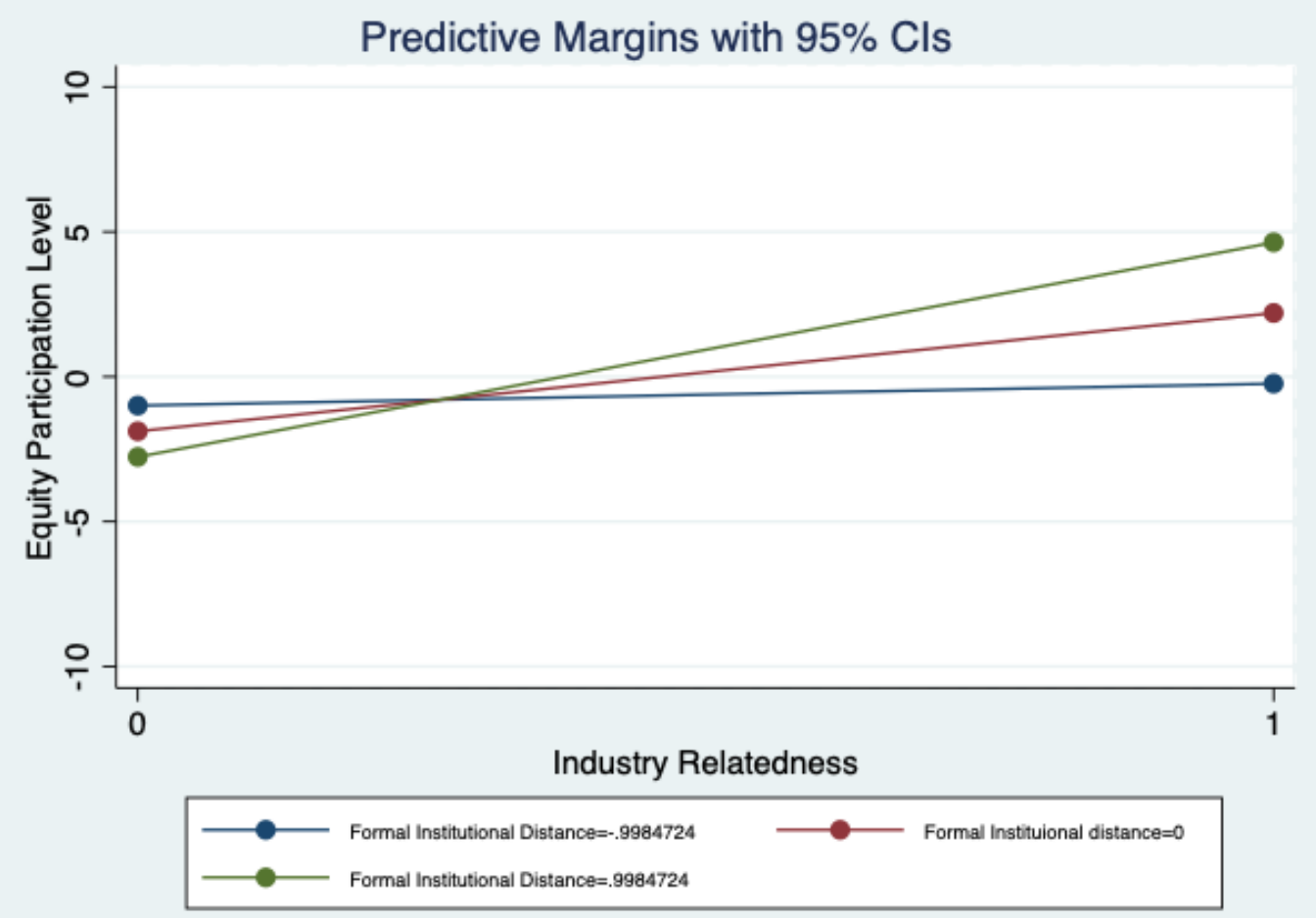

Figure 4. Moderating Role of Formal Institutional Distance on the relationship between Industry Relatedness and Acquisition Ownership Ratio 
Table 4: Formal Institutional Distance Levels

\begin{tabular}{lllllll}
\hline & B & SE & $\mathbf{t}$ & $\mathbf{P}$ & \% 95 CI & \\
\hline Z(Below) & 0.759 & 3.035 & 0.25 & 0.802 & -5.196 & 6.715 \\
Z(Mean) & 4.083 & 2.148 & 1.90 & 0.058 & -0.133 & 8.300 \\
Z(Above) & 7.406 & 3.207 & 2.31 & 0.021 & 1.113 & 13.700 \\
\hline
\end{tabular}

As seen in Figure 2, the effect of the industry relatedness variable on the equity participation level is insignificant when the formal institutional distance is below the mean $(\beta=0.759 ; \mathrm{p}>0.05)$ and is represented with the blue line. However, when the moderating variable takes a value above the mean which is represented by the green line, this relationship becomes significant and positive $(\beta=7,406$; $\mathrm{p}<0.05)$. When we look at the results of the simple slope analysis, the assumption of Hypothesis 2a that the formal institutional distance will weaken the relationship between the dependent and independent variables is not supported. On the contrary, the significant and positive effect of the acquirer and acquired company operating in the same industry on the ownership level seems to increase as the formal institutional distance is broaden. Similarly, in Figure 3 the relationship between the industry relatedness and ownership level is insignificant when the informal institutional distance is below the mean (blue line) $(\beta=-1.357 ; \mathrm{p}>0.05)$. However, when it gets a value above the mean (green line), this relationship becomes significant and positive $(\beta=7.406 ; p<0.05)$. In this case, Hypothesis $2 \mathrm{~b}$ is also not supported but provided the similar results like Hypothesis 2a. Like formal institutional distance, informal institutional distance also strengthens the positive relationship between industry relatedness and equity participation level when it takes higher values.

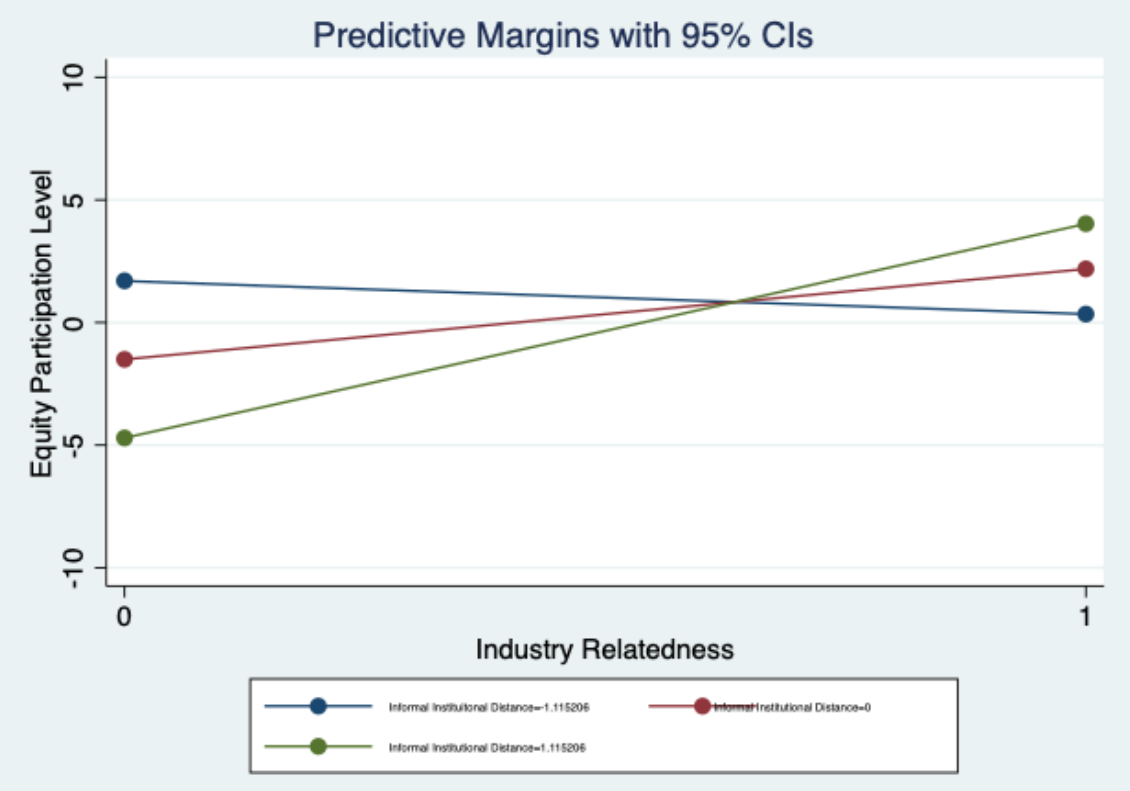

Figure 5. Moderating Role of Informal Institutional Distance on the relationship between Industry Relatedness and Acquisition Ownership Ratio 
Table 5: Informal Institutional Distance Levels

\begin{tabular}{lllllll}
\hline & B & SE & $\mathbf{t}$ & P & \% 95 CI & \\
\hline Z(Below) & -1.357 & 3.063 & -0.44 & 0.658 & -7.369 & 4.653 \\
Z(Mean) & 3.689 & 2.148 & 1.72 & 0.086 & -0.526 & 7.906 \\
Z(Above) & 8.737 & 3.017 & 2.90 & 0.004 & 2.816 & 14.658 \\
\hline
\end{tabular}

\section{Discussion and Conclusion}

In the present study, we aim to determine to what extent ownership level preferred by foreign MNEs in their cross-border merger and acquisition (CBMA) activities in Turkey is affected by the institutional and industrial context. According to the findings, we found that in the CBMA activities of foreign MNEs in Turkey, the fact that the acquirer and the acquired company operate in the same industry positively affects the percentage of equity acquired by MNEs in the target company. This result is similar to previous studies in the literature (Chari \& Chang, 2009; Chen \& Hennart, 2004; Contractor et al., 2014; Yang, 2015). MNEs seem to partially eliminate the uncertainty and information asymmetry they will encounter in their M\&A activities in a foreign market if they acquire companies operating in the same industry. As a result of reduced uncertainty, MNEs are willing to transfer more financial and social resources to the target company of the host country by increasing their level of equity ownership in the target company.

However, significant findings could not be obtained for the proposition that the high uncertainty environment created by underdeveloped formal institutions, especially in emerging countries such as Turkey, will reduce the advantage provided by the industry relatedness. At this point, partial findings have been obtained: when the acquirer and the acquired company operate in the same industry, in cases where the formal institutional distance is high, this affects positively the acquisition ownership level. This result contradicts with the theoretical conclusions envisaged in literature and need to be examined more in detail for future studies. In addition, the proposition that the increase in the cultural distance, which expresses the informal institutional distance between the home country and Turkey, will increase the uncertainty for MNEs thus will weaken the relationship between the acquisition equity level and industry relatedness was not supported. The results of the analysis have shown an opposite effect: the increase in cultural distance also increases the percentage of equity acquired by MNEs in the target company when the acquirer and acquired companies operating in the same industry. This may lead to the conclusion that foreign MNEs attribute more importance to industry knowledge than corporate institutional knowledge in their investments decisions in Turkey. In particular, controlling all or most of the equity shares of the target company may be seen as a more practical alternative to overcome the dissimilarities in the formal and informal institutional environment. Considering that formal institutional environmental factors do not have a significant effect, foreign MNEs may be more inclined to prefer as a management style to completely control the companies they acquire in emerging countries with their own management philosophy and methods. 
Based on transaction cost approach, the proposition that performing acquisition activities in similar industrial environments will reduce the uncertainty has been confirmed to a great extent in this study. Thus, we found support for transaction cost-based view in our study. However, the institutional environmental conditions including the industry context and the institutional-based perspective do not give the expected results in the context of a emerging country such as Turkey. Considering the finding that higher ownership level occurs in M\&A activities especially by developed country MNEs, institutional environmental conditions in Turkey have become more familiar to foreign MNEs as a result of their previous international investments and they are not affected by this situation can be considered as an alternative explanation to these findings.

As previous research in the field, our study has some limitations which can be removed by further studies. Firstly, we have used archived and secondary data sources to analyze our research model. Measuring the effect of informal institutions like culture on investment decisions may need more deeper or qualitative methods in FDI studies. Future research may elaborate the real impact of host country culture by asking MNEs' decision makers and top managers. Furthermore, our study only covers the sample of CBMAs in Turkey context which makes generalizing the results for all emerging countries with distinct attributions. Although, Turkey can be a valid example as a mid-range EM, scholars should investigate different EM contexts for CBMA studies in the future. Another limitation of our study is the need for more country specific variables which may impact inward FDI decisions of MNEs. Future research can eliminate this problem through in-depth qualitative or survey method studies by asking to both investor and target firms directly. Besides our study has not explored the motivations of MNEs while investing in Turkey. This topic would also invoke new research avenues for EM contexts.

\section{Yazar Katkısı}

\begin{tabular}{|l|l|l|}
\hline KATKI ORANI & AÇIKLAMA & KATKIDA BULUNANLAR \\
\hline Fikir veya Kavram & Araştırma fikrini veya hipotezini oluşturmak & $\begin{array}{l}\text { Ayşe KAYACI } \\
\text { Ömer DÜLEK }\end{array}$ \\
\hline Literatür Taraması & $\begin{array}{l}\text { Çalışma için gerekli literatürü taramak } \\
\text { Ayşe KAYACI } \\
\text { Aylin ATAAY }\end{array}$ \\
\hline Araştırma Tasarımı & $\begin{array}{l}\text { Çalışmanın yöntemini, ölçeğini ve desenini } \\
\text { tasarlamak }\end{array}$ & $\begin{array}{l}\text { Ayşe KAYACI } \\
\text { Aylin ATAAY }\end{array}$ \\
\hline Veri Toplama ve İşleme & $\begin{array}{l}|c| \\
\text { Verileri toplamak, düzenlemek ve raporlamak }\end{array}$ & $\begin{array}{l}\text { Ayşe KAYACI } \\
\text { Aylin ATAAY } \\
\text { Ömer DÜLEK }\end{array}$ \\
\hline Tartışma ve Yorum & $\begin{array}{l}\text { Bulguların değerlendirilmesinde } \\
\text { sonuçlandırılmasında sorumluluk almak }\end{array}$ & $\begin{array}{l}\text { Ayşe KAYACI } \\
\text { Ömer DÜLEK }\end{array}$ \\
\hline
\end{tabular}




\section{Çıkar Çatışması}

Çalışmada yazarlar arasında çıkar çatışması yoktur.

\section{Finansal Destek}

Bu çalışma için herhangi bir kurumdan destek alınmamıştır.

\section{References}

Aiken, L. S., \& West, S. G. (1991). Multiple Regression: Testing and Interpreting Interactions. Sage Publications.

Anderson, E., \& Gatignon, H. (1986). Modes of Foreign Entry: A Transaction Cost Analysis and Propositions. Journal of International Business Studies, 17(3), 1-26. https://doi.org/10.1057/palgrave.jibs.8490432

Arslan, A., \& Dikova, D. (2015). Influences of Institutional Distance and MNEs' Host Country Experience on the Ownership Strategy in Cross-Border M\&As in Emerging Economies. Journal of Transnational Management, 20(4), 231-256. https://doi.org/10.1080/15475.778.2015.1093784

Berry, H., Guillén, M. F., \& Zhou, N. (2010). An institutional approach to cross-national distance. Journal of International Business Studies, 41(9), 1460-1480. https://doi.org/10.1057/jibs.2010.28

Brouthers, K. D. (2002). Institutional, Cultural and Transaction Cost Influences on Entry Mode Choice and Performance. Journal of International Business Studies, 33(2), 203-221.

Brouthers, K. D., \& Hennart, J.-F. (2007). Boundaries of the Firm: Insights From International Entry Mode Research. Journal of Management, 33(3), 395-425. https://doi.org/10.1177/014.920.6307300817

Buckley, P. J., \& Casson, M. (1976). The Future of the Multinational Enterprise (1st ed.). London: Palgrave Macmillan.

Buckley, P. J., Elia, S., \& Kafouros, M. (2014). Acquisitions by emerging market multinationals: Implications for firm performance. Journal of World Business, 49(4), 611-632. https://doi.org/10.1016/J.JWB.2013.12.013

Caprio, L., Croci, E., \& Del Giudice, A. (2011). Ownership structure, family control, and acquisition decisions. Journal of Corporate Finance, 17(5), 1636-1657. https://doi.org/10.1016/J.JCORPFIN.2011.09.008

Cavusgil, S. T. (2021). Advancing knowledge on emerging markets: Past and future research in perspective. International Business Review, 30(2), 101796. https://doi.org/10.1016/J.IBUSREV.2021.101796

Chakrabarti, R., Gupta-Mukherjee, S., \& Jayaraman, N. (2009). Mars-Venus marriages: Culture and cross-border M \& A. Journal of International Business Studies, 40(2), 216-236. https://doi.org/10.1057/jibs.2008.58

Chari, M. D., \& Chang, K. (2009). Determinants of the share of equity sought in cross-border acquisitions. Journal of International Business Studies, 40(8), 1277-1297. https://doi.org/10.1057/jibs.2008.103

Chen, S.-F. S. (2008). The motives for international acquisitions: capability procurements, strategic considerations, and the role of ownership structures. Journal of International Business Studies, 39(3), 454-471. https://doi.org/10.1057/palgrave.jibs.8400357

Chen, S.-F. S., \& Hennart, J.-F. (2004). A hostage theory of joint ventures: why do Japanese investors choose partial over full acquisitions to enter the United States? Journal of Business Research, 57(10), 1126-1134. https://doi.org/10.1016/S0148-2963(03)00041-9

Colpan, A. M., \& Hikino, T. (2008). Türkiye’nin Büyük Şirketler Kesiminde İşletme Gruplarının İktisadi Rolü ve Çeşitlendirme Stratejileri. Yönetim Araştırmaları Dergisi, 8(1), 23-58.

Contractor, F. J., Lahiri, S., Elango, B., \& Kundu, S. K. (2014). Institutional, cultural and industry related determinants of ownership choices in emerging market FDI acquisitions. International Business Review, 23(5), 931-941. https://doi.org/10.1016/j.ibusrev.2014.02.005 
Demirbag, M., Glaister, K. W., \& Tatoglu, E. (2007). Institutional and transaction cost influences on MNEs' ownership strategies of their affiliates: Evidence from an emerging market. Journal of World Business, 42(4), 418-434. https://doi.org/10.1016/j.jwb.2007.06.004

Demirbag, M., Tatoglu, E., \& Glaister, K. W. (2008). Factors affecting perceptions of the choice between acquisition and greenfield entry: The case of Western FDI in an emerging market. Management International Review, 48(1), 5-38. https://doi.org/10.1007/s11575.008.0002-3

Di Guardo, M. C., Marrocu, E., \& Paci, R. (2016). The effect of local corruption on ownership strategy in cross-border mergers and acquisitions. Journal of Business Research, 69(10), 4225-4241. https://doi. org/10.1016/j.jbusres.2016.03.002

Dikova, D. (2009). Performance of foreign subsidiaries: Does psychic distance matter? International Business Review, 18(1), 38-49. https://doi.org/https://doi.org/10.1016/j.ibusrev.2008.11.001

Erdal, F., \& Tatoglu, E. (2002). Locational determinants of foreign direct investment in an emerging market economy: evidence from Tukey. Multinational Business Review, 10, 21-27.

Fitzsimons, G. J. (2008). Death to Dichotomizing. Journal of Consumer Research, 35(1), 5-8. https://doi. org/10.1086/589561

Gatignon, H., \& Anderson, E. (1988). The Multinational Corporation's Degree of Control over Foreign Subsidiaries: An Empirical Test of a Transaction Cost Explanation. Journal of Law, Economics, \& Organization, 4(2), 305-336. Retrieved from http://www.jstor.org/stable/764925

Haleblian, J., Devers, C. E., McNamara, G., Carpenter, M. A., \& Davison, R. B. (2009). Taking stock of what we know about mergers and acquisitions: A review and research agenda. Journal of Management, 35(3), 469-502. https://doi.org/10.1177/014.920.6308330554

Hofstede, G. (2001). Culture's Consequences: Comparing Values, Behaviors, Institutions, and Organizations Across Nations. In Culture's Consequences: Comparing Values, Behaviors, Institutions, and Organizations Across Nations (2nd ed.). Retrieved from https://digitalcommons.usu.edu/unf_research/53

Hoskisson, R. E., Wright, M., Filatotchev, I., \& Peng, M. W. (2013). Emerging Multinationals from Mid-Range Economies: The Influence of Institutions and Factor Markets. Journal of Management Studies, 50(7), 1295-1321. https://doi.org/10.1111/j.1467-6486.2012.01085.x

Kaufmann, D., Kraay, A., \& Mastruzzi, M. (2011). The Worldwide Governance Indicators: Methodology and Analytical Issues. Hague Journal on the Rule of Law, 3(02), 220-246. https://doi.org/10.1017/ S187.640.4511200046

Khanna, T., \& Palepu, K. G. (1997). Why Focused Strategies May Be Wrong for Emerging Markets. Harvard Business Review, (July-August).

Khanna, T., \& Rivkin, J. W. (2001). Estimating the Performance Effects of Business Groups in Emerging Markets. Strategic Management Journal, 22(1), 45-74. https://doi.org/10.1002/1097-0266(200101)22:1<45::AIDSMJ147>3.0.CO;2-F

Kostova, T., \& Zaheer, S. (1999). Organizational Legitimacy under Conditions of Complexity : The Case of the Multinational Enterprise. The Academy of Management Review, 24(1), 64-81.

Lahiri, S. (2017). The moderating influence of market potential and prior experience on the governance qualityequity participation relationship: Evidence from acquisitions in BRIC. Management Decision, 55(1), 203-217. https://doi.org/10.1108/MD-06-2016-0408

Lahiri, S., Elango, B., \& Kundu, S. K. (2014). Cross-border acquisition in services: Comparing ownership choice of developed and emerging economy MNEs in India. Journal of World Business, 49(3), 409-420. https:// doi.org/10.1016/J.JWB.2013.08.003 
Lim, M.-H., \& Lee, J.-H. (2016). The effects of industry relatedness and takeover motives on cross-border acquisition completion. Journal of Business Research, 69(11), 4787-4792. https://doi.org/10.1016/J. JBUSRES.2016.04.031

Liou, R.-S., Chao, M. C., \& Ellstrand, A. (2017). Unpacking Institutional Distance: Addressing Human Capital Development and Emerging-Market Firms' Ownership Strategy in an Advanced Economy. Thunderbird International Business Review, 59(3), 281-295. https://doi.org/10.1002/tie.21839

Malhotra, S., Lin, X., \& Farrell, C. (2016). Cross-national uncertainty and level of control in cross-border acquisitions: A comparison of Latin American and U.S. multinationals. Journal of Business Research, 69(6), 1993-2004. https://doi.org/10.1016/J.JBUSRES.2015.10.145

Malhotra, S., Sivakumar, K., \& Zhu, P. C. (2011). Curvilinear relationship between cultural distance and equity participation: An empirical analysis of cross-border acquisitions. Journal of International Management, 17(4), 316-332. https://doi.org/10.1016/j.intman.2011.06.001

Morosini, P., Shane, S., \& Singh, H. (1998). National Cultural Distance and Cross-Border Acquisition Performance. Journal of International Business Studies, 29(1), 137-158. https://doi.org/10.1057/palgrave. jibs.8490029

North, D. (1990). Institutions, institutional change, and economic performance. Economic Perspective, 5(1), 97 112.

Peng, M. W., Sun, S. L., Pinkham, B., \& Chen, H. (2009). The Institution-Based View as a Third Leg for a Strategy Tripod. Academy of Management Perspectives, 23(3), 63-81. https://doi.org/10.5465/ AMP.2009.434.79264

Shimizu, K., Hitt, M. A., Vaidyanath, D., \& Pisano, V. (2004). Theoretical foundations of cross-border mergers and acquisitions: A review of current research and recommendations for the future. In Journal of International Management (Vol. 10). https://doi.org/10.1016/j.intman.2004.05.005

UNCTAD. (2005). World Investment Report: Transnational Corporations and the Internationalization of R\&D.

UNCTAD. (2019). World Investment Report 2019:Special Economic Zones.

UNCTAD. (2021). UNCTAD FDI Statistics.

Williamson, O. E. (1979). Transaction-Cost Economics : The Governance of Contractual Relations. The Journal of Law \& Economics, 22(2), 233-261.

Yang, M. (2015). Ownership participation of cross-border mergers and acquisitions by emerging market firms. Management Decision, 53(1), 221-246. https://doi.org/10.1108/MD-05-2014-0260

Yin, X., \& Shanley, M. (2008). Industry determinants of the "merger versus alliance" decision. Academy of Management Review, 33(2), 473-491. https://doi.org/10.5465/AMR.2008.311.93515

\section{Resume}

Ayşe KAYACI (Assist. Prof.), She works as an assistant Professor at Dicle University Faculty of Economics and Administrative Sciences. She has a Ph.D in management and organization studies from Galatasaray University, Istanbul. Her main research interests are emerging markets, internationalization of emerging market multinational corporations and business groups with a special interest in internationalization of Turkish MNCs and business groups

Aylin ATAAY (Prof. Dr.), She is professor of management at Galatasaray University, Istanbul. She received her Ph.D. in strategic management from the IAE - Paris 1 Panthéon - Sorbonne University and Istanbul University. Her recent research interests are in the area of international management, 
corporate governance and top management teams of business groups, with a specific focus on top managers' succession and compensation.

Ömer DÜLEK (Res. Asst.), He works at Dicle University Faculty of Economics and Administrative Sciences. His main research fields are management and organization. 